\title{
ANALISIS RISIKO PADA PENGALIHAN AKAD PEMBIAYAAN DI BANK SYARIAH
}

\author{
Muawanah \\ Institut Pesantren KH. Abdul Chalim Mojokerto \\ Email: anadarto54@gmail.com
}

\begin{abstract}
An Indonesian country with a majority of its population embracing Islam wants a banking institution in accordance with Islamic sharia that is free from the elements of riba, maysir, and gharar, the presence of Islamic banks as a solution.Initially, Islamic banks only knew about savings or deposit products with wadiah and mudaraba contracts. Similarly, in the sector of fund disbursement, Bank Indonesia in Bank Indonesia regulations, then regulates products with mudharabah, musyarakah, murabahah, salam, istishna, ijarah, and ijarah muhtahiya bittamlik contracts. Even though the needs of the community are developing, so that an assessment is needed so that community needs can be accommodated in contracts that do not conflict with sharia principles.Murabahah contract financing is an alternative financing model in the procurement of goods. Through this murabahah financing, customers will find it easy to repay payments in the amount that is in accordance with what the bank agrees. As for the banks' footing, this murabahah financing is a contract of funds distribution quickly and easily and many applicants are compared to other contracts.
\end{abstract}

Keywords: Transfer, Financing Agreement, Sharia Bank

\begin{abstract}
ABSTRAK
Negara Indonesia yang mayoritas penduduknya memeluk agama Islam menginginkan adanya lembaga perbankan yang sesuai dengan syariah Islam yang bebas dari unsur riba, maysir, dan gharar hadirnya bank syariah sebagai solusi Pada Bank Syariah awalnya masyarakat hanya mengenal produk tabungan atau deposito dengan akad wadiah dan mudharabah. Demikian halnya di sektor penyaluran dana, Bank Indonesia dalam Peraturan Bank Indonesia, barulah mengatur produk dengan akad mudharabah, musyarakah, murabahah, salam, istishna, ijarah, dan ijarah muntahiya bit tamlik. Padahal kebutuhan masyarakat berkembang, sehingga perlu pengkajian agar kebutuhan masyarakat dapat diakomodasi dalam akad-akad yang tidak bertentangan dengan prinsip syariah.Pembiayaan dengan akad murabahah merupakan model pembiayaan alternatif dalam pengadaan barang-barang kebutuhan. Melalui pembiaayaan murabahah inilah nasabah akan mendapatkan kemudahan dalam mengansur pembayaran dengan jumlah sesuai dengan yang disepakati pihak bank. Sedangkan bagi pihak bank, pembiayaan murabahah ini merupakan akad penyaluran dana dengan cepat dan mudah dan banyak peminatnya dibandingkan dengan akad yang lainnya.
\end{abstract}

Kata Kunci: Pengalihan, Akad Pembiayaan, Bank Syariah

\section{PENDAHULUAN}

Lembaga perbankan merupakan salah satu aspek yang diatur dalam syariah Islam. Fungsi utama bank adalah memenuhi kehendak ekonomi masyarakat dan 
bersamaan dengan perkembangan peradaban. ${ }^{1}$ Perkembangan zaman di era globalisasi menjadikan masyarakat dituntut untuk dapat memenuhi kebutuhannya secara cepat dan praktis, sehingga masyarakat sekarang ini sudah terbiasa dengan hal pinjam meminjam dalam memenuhi suatu kebutuhan hidupnya. Dalam hal inilah salah satu penyebab masyarakat modern saat ini tidak dapat menghindari untuk melakukan transaksi salah satunya dalam dunia perbankan. Usaha perbankan sebagaimana diketahui bukanlah badan usaha biasa seperti halnya perusahaan yang bergerak dibidang perdagangan dan jasa, melainkan suatu badan usaha yang bergerak di bidang jasa keuangan. ${ }^{2}$

Kegiatan dari bank konvensional mengikuti dasar dan prinsip-prinsip perbankan yang sudah ada sejak bank pertama kali didirikan. Pada bank konvensional, kepentingan pemilik dana adalah memperoleh imbalan berupa bunga simpanan yang tinggi, sedangkan kepentingan pemegang saham adalah diantaranya memperoleh dan mengoptimalkan antara suku bunga simpanan dan suku bunga pinjaman. Lain halnya dengan bank syariah, bank syariah adalah bank yang memakai dasar syariah Islam dan menjalankan usahanya dengan prinsip syariah yang mengacu kepada Al-Quran dan AlHadits. ${ }^{3}$ Prinsip syariah adalah aturan perjanjian berdasarkan hukum Islam antara bank dan pihak lain untuk menyimpan dana, pembiayaan kegiatan usaha atau kegiatan lainnya sesuai dengan prinsip syariah. ${ }^{4}$

Di Indonesia sendiri dengan penduduk mayoritas memeluk agama Islam menginginkan adanya lembaga perbankan yang sesuai dengan syariah Islam yang bebas dari unsur riba, maysir, dan gharar. Pengertian dari riba sendiri secara bahasa artinya az-ziadah atau tambahan, dalam fiqh riba adalah tambahan atas modal, sedikit ataupun banyak. ${ }^{5}$ Maysir menurut Muhammad Ayub artinya permainan yang mengadu keberuntungan atau kata lain bertaruh (game of chance) atau dapat disebut dengan

\footnotetext{
${ }^{1}$ Muhammad Muslehuddin, Sistem Perbankan dalam Islam (Jakarta :PT. Rineka Cipta, 2004), 25.

${ }^{2}$ Yohanes Benny Apriyanto Dan FX. Suhardana, "Penyelesaian Kredit Bermasalah Pada Bank DKI Jakarta Cabang Solo Melalui Jalur Non Litigasi”, Jurnal Hukum Fakultas Hukum Universitas Atma Jaya Yogyakarta, 2015, 3.

${ }^{3}$ Gatot Supramono, Perbankan dan Masalah Kredit (Jakarta, Rineka Cipta, 2009), 134.

${ }^{4}$ M. Syafi'i Antonio, Bank Syariah Dari Teori Ke Praktek (Jakarta: Gema Insani, 2011), 101.

${ }^{5}$ Gemala Dewi, Aspek-aspek Hukum dalam Perbankan dan Perasuransian Syariah, cet. 3 (Jakarta: Kencana Prenada Media Group, 2006), 43.
} 
perjudian (gambling and wagering). ${ }^{6}$ Dan definisi dari gharar menurut Imam malik adalah jual-beli objek yang belum ada wujudnya dan dengan itu belum diketahui dengan jelas kualitas barang tersebut oleh pembeli apakah barang tersebut berkualitas baik atau buruk. ${ }^{7}$

Masyarakat hanya mengenal produk tabungan atau deposito dengan akad wadiah dan mudharabah Demikian halnya di sektor penyaluran dana, Bank Indonesia dalam Peraturan Bank Indonesia, barulah mengatur produk dengan akad mudharabah, musyarakah, murabahah, salam, istishna, ijarah, dan ijarahmuntahiya bit tamlik. ${ }^{8}$ Padahal kebutuhan masyarakat berkembang, sehingga perlu pengkajian agar kebutuhan masyarakat dapat diakomodasi dalam akad-akad yang tidak bertentangan dengan prinsip syariah.

Pembiayaan dengan akad murabahah merupakan model pembiayaan alternatif dalam pengadaan barang-barang kebutuhan. Melalui pembiaayaan murabahah inilah nasabah akan mendapatkan kemudahan dalam mengansur pembayaran dengan jumlah sesuai dengan yang disepakati pihak bank. Sedangkan bagi pihak bank, pembiayaan murabahah ini merupakan akad penyaluran dana dengan cepat dan mudah dan banyak peminatnya dibandingkan dengan akad yang lainnya. Melalui murabahah bank syariah juga mendapatkan profit berupa margin dari selisih pembelian dan penjualan, serta mendapatkan fee based income (administrasi, komisi asuransi dan komisi notaris). Sedangkan yang menjadi pertanyaan, bagaimana status kepemilikan barang tersebut? apakah akan terjadi pengalihan akad kepemilikan barang sebelum dan sesudah pembelian? Di dalam makalah ini akan menjelaskan tentang pengalihan akad dari wakalah menjadi murabahah.

\section{PENGERTIAN PENGALIHAN AKAD}

Kesepakatan ahli Hukum Islam (Jumhur Ulama) mendefinisikan akad adalah suatu perikatan antara ijab dan qobul dengan cara yang dibenarkan syar'i yang

\footnotetext{
${ }^{6}$ Sutan Remi Sjahdeini, Perbankan Syariah: Produk-produk dan Aspek-aspek Hukumnya, cet. 1 (Jakarta: PT. Jayakarta Agung Offset, 2010), 161.

${ }^{7}$ Ibid,.

${ }^{8}$ Destri Budi Nugraheni, “Analisis Yuridis Multi Akad Dalam Pembiayaan Pengalihan Hutang Pada PT BRI Syariah" Jurnal Mimbar Hukum Fakultas Hukum Universitas Gadjah Mada Yogyakarta Vol. 27, No. 2, 2015, 2.
} 
menetapkan adanya akibat-akibat hukum pada obyeknya. Terjadinya suatu perikatan Islam (al 'aqdu) ini tidak terlalu jauh berbeda dengan terjadinya perikatan yang didaasarkan dengan buku III KUH Perdata, yang mana definisi hukum perikatan adalah suatu hubungan hukum dalam lapangan harta kekayaan antara dua orang atau lebih di mana pihak yang satu berhak atas sesuatu dan pihak yang lain berhak atas sesuatu. ${ }^{9}$

\section{PEMBIAYAAN AKAD WAKALAH}

Beberapa ahli, baik dari kalangan dunia perbankan maupun ulama' mengungkapkan beberapa pendapat tentang pengertian wakalah dengan redaksi yang bervariasi. Hashbi ash-Shiddieqy mengatakan bahwa wakalah adalah "akad penyerahan kekuasaan, yang pada akad itu seseorang menunjuk orang lain sebagai penggantinya dalam bertindak (bertasharruf)" ${ }^{10}$

Dalam konteks perbankan, Wirdiyaningsih mendefinisikan al-wakalah yaitu jasa melakukan tindakan/pekerjaan mewakili nasabah sebagai pemberi kuasa. Untuk mewakili nasabah melakukan tindakan/pekerjaan tersebut nasabah diminta untuk mendepositokan dana secukupnya. ${ }^{11}$ Helmi Karim memberikan definisi wakalah yaitu perlindungan (alhifzh), percukupan (al-kifayah), tanggungan (al-dhaman), atau pendelegasian (al-tafwidh), yang diartikan pula dengan memberikan kuasa atau mewakilkan. ${ }^{12} \mathrm{Jadi}$, wakalah dapat dikatakan sebagai akad penyerahan kekuasaan kepada seseorang yang telah dipercayainya sebagai perwakilan nasabah tersebut dalam bertransaksi sebagai pemberi kuasa.

Wakalah dalam aplikasi perbankan terjadi apabila nasabah memberikan kuasa kepada bank untuk mewakili dirinya melakukan pekerjaan jasa tertentu, seperti pembukuan L/C (Letter OfCredit Import Syariah \& Letter Of Credit Eksport Syariah), Inkaso dan Transfer uang, Penitipan, Anjak Piutang (Factoring), Wali Amanat, Investasi Reksadana Syariah, Pembiayaan Rekening Koran Syariah, Asuransi Syariah. ${ }^{13}$

\section{PEMBIAYAAN AKAD MURABAHAH}

\footnotetext{
9 Martha Tona, “Akuntansi Akad Ijarah Muntahiyyah Bittamlik: Perspektif Metode Maqashid al Syariah", Jurnal Akuntansi Syariah STIE Mahardhika, 2012, 5.

${ }^{10}$ Hasbi ash Shiddeqy, Pengantar Fiqh Muamalah (Jakarta: Bulan Bintang, 1974), 90.

${ }^{11}$ Wirdiyaningsih, Bank dan Asuransi Islam di Indonesia, cet. Ke-1 (Jakarta: Kencana, , 2005), 166.

${ }^{12}$ Helmi Karim, M.A, Fiqh Muamalah cet. I (Jakarta :PT. Raja Grafindo Persada, 1993), 20.

${ }^{13}$ Indah Nuhyatia, "Penerapan Dan Aplikasi Akad Wakalah Pada Produk Jasa Bank Syariah", Economic: Jurnal Ekonomi Dan Hukum Islam UIN Syarif Hidayatullah, Vol.3, No. 2, 2013, 1.
} 
Produk murabahah ini merupakan produk pembiayaan di mana pihak bank dapat sebagai mediasi antara pihak yang berkepentingan, yaitu nasabah dan developer atau pemasok, maksudnya dalam hal ini adalah apabila nasabah menginginkan memiliki atau membeli sesuatu barang dari developer sementara nasabah belum memiliki dana yang cukup untuk dapat membelinya, maka bank dalam hal ini memberikan bantuan berupa pembiayaan dengan cara membeli barang yang diinginkan oleh nasabah terlebih dahulu dari developer, kemudian pihak bank menjual kembali barang tersebut kepada nasabah dengan harga sesuai dengan pembelian pihak bank dari pihak developer dengan metode angsuran dan ditambah keuntungan bagi pihak bank yang telah disepakati antara pihak bank dan pihak nasabah sebelum transaksi jual-beli dilakukan. $^{14}$

Menurut Adiwarman A karim menyatakan bahwa murabahah adalah akad jual beli barang dengan menyatakan harga perolehan dan keuntungan (margin) yang disepakati oleh penjual dan pembeli. ${ }^{15}$ Adapun menurut Fiqh madzhab Syafi'i mengatakan bahwa murabahah adalah menyebutkan harga pokok yang dibeli kepada orang yang akan membeli, dengan memberi syarat supaya barang tersebut diberi untung. ${ }^{16}$ Sedangkan menurut Zaenul Arifin menyatakan bahwa murabahah sebagai jual beli dimana harga dan keuntungan disepakati antara penjual dan pembeli. ${ }^{17} \mathrm{Jadi}$, murabahah adalah suatu akad jual beli dimana penjual dan pembeli harus saling mengetahui harga pokok penjualan serta keuntungan yang di dapatkan oleh penjual.

Landasan syariah dibolehkannya murabahah adalah QS. An-Nisa':29, QS. AlBaqarah: 275 yang artinya sebagai berikut :

$$
\text { يآيها الذين آمنوا لاتأكلوا اموالكم بينكم بالباطل إلآ أنتكون تجارةً عن تراضٍ منكم }
$$

\footnotetext{
${ }^{14}$ Bagya Agung Prabowo, "Konsep Akad Murabahah Pada Perbankan Syariah (Analisis Kritis Terhadap Aplikasi Konsep Akad Murabahah Di Indonesia Dan Malaysia)", Jurnal Hukum Fakultas Hukum UII Yogyakarta No. 1 Vol. 16, Januari 2009, 4.

${ }^{15}$ Adiwarman A karim, Bank Islam: Analisis Fiqh dan Keuangan, cet. Ke-2 (Jakarta : PT. Raja Grafindo Persada, 2004), 103.

${ }^{16}$ Idris Ahmad, Fiqh Menurut Madzhab Syafi' 'i, jilid II cet. Ke-1 (Jakarta: Widjaya, 1969), 30.

${ }^{17}$ Zaenul Arifin, Memahami Bank Syari'ah Lingkup Peluang, Tantangan dan Prospek (Jakarta: Alvabert, 2001), 21.
} 
"Hai orang-orang yang beriman, janganlah kamu saling memakan harta sesamamu dengan jalan yang batil, kecuali ada transaksi diantaramu’. (QS. An-Nisa ayat: 29)

Mengenai utang dalam murabahah, ketentuan bagian keempat fatwa Dewan Syariah Nasional Majelis Ulama Indonesia Nomor 04/DSN-MUI/IV/2000 tentang murabahah mengatur sebagai berikut: ${ }^{18}$

1. Secara prinsip, peneyelesaian utang nasabah dalam transaksi murabahah tidak ada kaitannya dengan transaksi lain yang dilakukan nasabah dengan pihak ketiga atas barang tersebut. jika nasabah menjual kembali barang tersebut dengan keuntungan atau kerugian, ia tetap berkewajiban untuk menyelesaikan utangnya kepada bank.

2. Jika nasabah menjual barang tersebut sebelum masa angsuran berakhir, ia wajib segera melunasi seluruh angsurannya.

3. Jika penjualan barang tersebut menyebabkan kerugian, nasabah tetap harus menyelesaikan hutangnya sesuai kesepakatan awal. Ia tidak boleh memperlambat pembayaran angsuran atau meminta kerugian itu diperhitungkan.

Berdasarkan data yang dikeluarkan Bank Indonesia ditunjukan bahwa produk pembiayaan yang disalurkan oleh bank syariah masih tinggi peminatnya di kalangan masyarakat. Hal ini terbukti dari tujuh tahun terakhir jumlah angka pembiayaan terus meningkat. Produk yang sangat diminati nasabah adalah murabahah yakni mencapai sekitar 46, 161 miliar pada bulan juni 2012 dan yang kedua adalah produk pembiayaan musyarakah yakni mencapai 16, 295 miliar pada bulan juni 2012.19

\footnotetext{
${ }^{18}$ Fatwa DSN-MUI/IV/2000 Tentang Murabahah

19 Muhammad Yusuf, "Analisis Penerapan Pembiayaan Murabahah Berdasarkan Pesanan Dan Tanpa Pesanan Serta Kesesuaian Dengan PSAK 102”, Jurnal Binus Business Review Vol. 4 No. 1, Mei 2013, 2.
} 
Tabel 2 Komposisi Pembiayaan yang Diberikan Bank Syariat

(Dalam Miliar Rupiah)

\begin{tabular}{lcccccccc}
\hline \multicolumn{1}{c}{ Akad } & $\mathbf{2 0 0 5}$ & $\mathbf{2 0 0 6}$ & $\mathbf{2 0 0 7}$ & $\mathbf{2 0 0 8}$ & $\mathbf{2 0 0 9}$ & $\mathbf{2 0 1 0}$ & $\mathbf{2 0 1 1}$ & $\begin{array}{c}\mathbf{2 0 1 2} \\
\text { (juni) }\end{array}$ \\
\hline Mudharabah & 3,124 & 4,062 & 5,578 & 6,205 & 6,597 & 8,631 & 10,229 & 9,549 \\
Musyarakah & 1,898 & 2,335 & 4,406 & 7,411 & 10,412 & 14,624 & 18,960 & 16,295 \\
Murabahah & 9,487 & 12,624 & 16,553 & 22,486 & 26,321 & 37,508 & 56,365 & 46,161 \\
Salam & 0 & 0 & 0 & 0 & 0 & 0 & 0 & 0 \\
Istishna & 282 & 337 & 351 & 369 & 423 & 347 & 326 & 322 \\
Ijarah & 316 & 836 & 516 & 765 & 1,305 & 2,341 & 3,839 & 2,927 \\
Qard & 125 & 250 & 540 & 959 & 1,829 & 4,731 & 12,937 & $\mathbf{7 , 3 6 2}$ \\
\hline Total & $\mathbf{1 5 , 2 3 3}$ & $\mathbf{2 0 , 4 4 5}$ & $\mathbf{2 7 , 9 4 4}$ & $\mathbf{3 8 , 1 9 5}$ & $\mathbf{4 6 , 8 8 6}$ & $\mathbf{6 8 , 1 8 1}$ & $\mathbf{1 0 2 , 6 5 5}$ & $\mathbf{8 2 , 6 1 6}$ \\
& \multicolumn{7}{c}{ Sumber: Statistik Perbankan Syari'ah Bank Indonesia } \\
\end{tabular}

Masing-masing akad tersebut sesuai karakteristiknya dapat diterapkan dalam operasional perbankan syariah dalam produk penghimpunan dana (funding), penyaluran dana (financing), dan jasa (service).

\section{PENGALIHAN AKAD}

Perkembangan perbankan syariah saat ini telah mengalami kemajuan yang pesat berkat dukungan berbagai pihak dan ketersediaan yang memberikan kemudahan dalam perkembangan perbankan syariah.Suatu kelaziman dalam dunia perbankan apabila hendak memberikan pembiayaan yang pembayarannya dilakukan dengan kredit oleh nasabah bank mensyaratkan agar sebagian total kredit itu ditutup dari modal nasabah sendiri, yang dalam istilah perbankan dikenal dengan self financing.

Hasil penelitian yang dilakukan oleh Hariyanto menunjukkan bahwa porsi uang muka pada Bank Kalsel Cabang Syariah Banjarmasin ditetapkan berdasarkan harga barang dan kondisi barang. uang muka diakui sebagai bagian dari pembayaran piutang murabahah. uang muka yang diterapkan oleh Bank Kalsel Syariah Banjarmasin telah sesui dengan Fatwa DSN, PSAK, dan PAPSI. Untuk pembayaran uang muka ada 2 variasi, yang pertama nasabah membayar uang muka ke bank, dan yang kedua nasabah membayar uang muka langsung ke supplier menggunakan akad wakalah. ${ }^{20}$

Setidaknya untuk produk pembiayaan murabahah (jual beli yang keuntungannya disepakati antara bank dan nasabah). Karena murabahah itu jual beli, maka penjual (bank) dapat mensyaratkan sejumlah uang muka kepada pembeli

\footnotetext{
${ }^{20}$ Hariyanto, “Analisis Perlakuan Akuntansi Uang Muka Murabahah Pada Bank Kalsel Cabang Syariah Banjarmasin”, Jurnal At-Taradhi Jurnal Studi Ekonomi Fakultas Syariah Dan Ekonomi Islam IAIN Antasari, Volume 6 No 1, Juni 2015, 2.
} 
(nasabah) apabila ingin membeli barang. Apabila transaksi ini jadi dilaksanakan, maka uang muka tersebut akan menjadi sebagian dari harga yang dibayar. Tetapi jika transaksinya batal, maka uang muka itu dikembalikan kepada nasabah setelah diperhitungkan biaya administrasi dan kerugian yang mungkin akan diderita bank akibat pembatalan itu. ${ }^{21}$

\section{PENYEBAB TERJADINYA PENGALIHAN AKAD}

Konsep anjak piutang (factoring) yang berdasarkan prinsip syariah sering dikatakan sama dengan istilah hiwalah, karena secara operasional mirip dengan pelaksanaan hiwalah diperbankan syariah. Perjanjian pengalihan piutang atau anjak piutang (factoring) dalam fiqh muamalah disebut dengan istilah hiwalah. ${ }^{22}$

Sangat disayangkan di Indonesia saat ini dalam prakteknya masih terjadi penyimpangan dalam hal menerapkan akad murabahah dan pelaksanaannya. Seperti yang telah kita ketahui bahwa akad murabahah adalah akad jual beli barang pada harga asal dengan tambahan keuntungan yang disepakati. Rukun murabahah sendiri antara lain adanya penjual (bai') dalam hal ini dapat dilakukan oleh bank sebagai pihak yang menyediakan barang yang hendak dimiliki oleh konsumen (nasabahnya), pembeli (musytari') yakni nasabah dari bank yang bersangkutan, barang/obyek (mabi'), ijab qabul (sighat). ${ }^{23}$

Namun menurut hasil penelitian Rahmah Adisty pada kenyataannya terdapat akad-akad murabahah yang diikat oleh pihak Bank Syariah dan nasabahnya yang tidak memenuhi rukun ini. Berdasarkan latar belakang tersebut maka penulis melakukan penelitian hukum untuk mengetahui penerapan murabahah dalam akad dan pelaksanaannya ditinjau dari hukum Islam berkaitan dengan sengketa yang telah diputus oleh Mahkamah Agung dengan Putusan no 48 PK/AG/2009 dimana sebelumnya telah diputus oleh Pengadilan Agama Bukit Tinggi dengan Putusan No.284/Pdt.G/2006/PA.Bkt, Pengadilan Tinggi Agama Padang dengan Putusan no. 32 dan 33/Pdt.G/2007/PTA.Pdg, dan Mahkamah Agung pada tingkat kasasi dengan Putusan No. 292 K/AG/2008 antara Bank Syariah X dengan nasabah pada akad

\footnotetext{
${ }^{21}$ Sri Nurhayati, dan Wasilah, Akuntansi Syariah di Indonesia, Edisi II (Jakarta: Salemba Empat, 2011), $169-170$.

${ }^{22}$ Burhanuddin S, Hukum Kontrak Syariah (Yogyakarta: BPPE Jogjakarta, 2009), 75.

${ }^{23}$ Sunarto Zulkifli, Panduan Praktis Transaksi Perbankan Syariah, (Jakarta: Zikrul Hakim, 2003), 40.
} 
pertama yang diikat dengan akad murabahah No. 2 tanggal 2 Juli 2003 dan akad kedua yang juga diikat dengan akad murabahah No. 43 tanggal 27 Agustus 2003, serta dikaitkan dengan hukum positif yang telah mengatur mengenai murabahahpada masa itu, dan perkembangan hukum positif yang mengatur mengenai akad murabahah tersebut hingga saat ini. ${ }^{24}$

Akan tetapi, hal ini sangat bertentangan dengan yang diatur dalam Fatwa Dewan Syariah Nasional (DSN) Majelis Ulama Indonesia (MUI) Nomor 67 Tahun 2008 tentang Anjak Piutang Syariah. Dalam Fatwa DSN-MUI Nomor. 67 Tahun 2008 tentang Anjak Piutang ditegaskan bahwa akad yang dapat digunakan dalam anjak piutang secara syariah adalah wakalah bil ujrah. ${ }^{25}$ Dalam akhir tahapan proses pembiayaan yaitu penyerahan barang setelah dilakukan dan dipenuhi segala prosedur dan mekanisme pembiayaan murabahah yang ada, maka barang tersebut menjadi hak milik nasabah yang selaku sebagai pembeli.

\section{PENYELESAIAN PENGALIHAN AKAD}

Dalam prakteknya, pembiayaan murabahah di BPR Syari’ah Asad Alif Sukorejo Kendal dilaksanakan dalam satu transaksi dengan wakalah, yaitu upaya pemberian kekuasaaan pada nasabah untuk membeli barang yang diinginkan secara mandiri. ${ }^{26}$ Atau lebih jelasnya kita lihat skema pembiayaan murabahah dibawah ini:

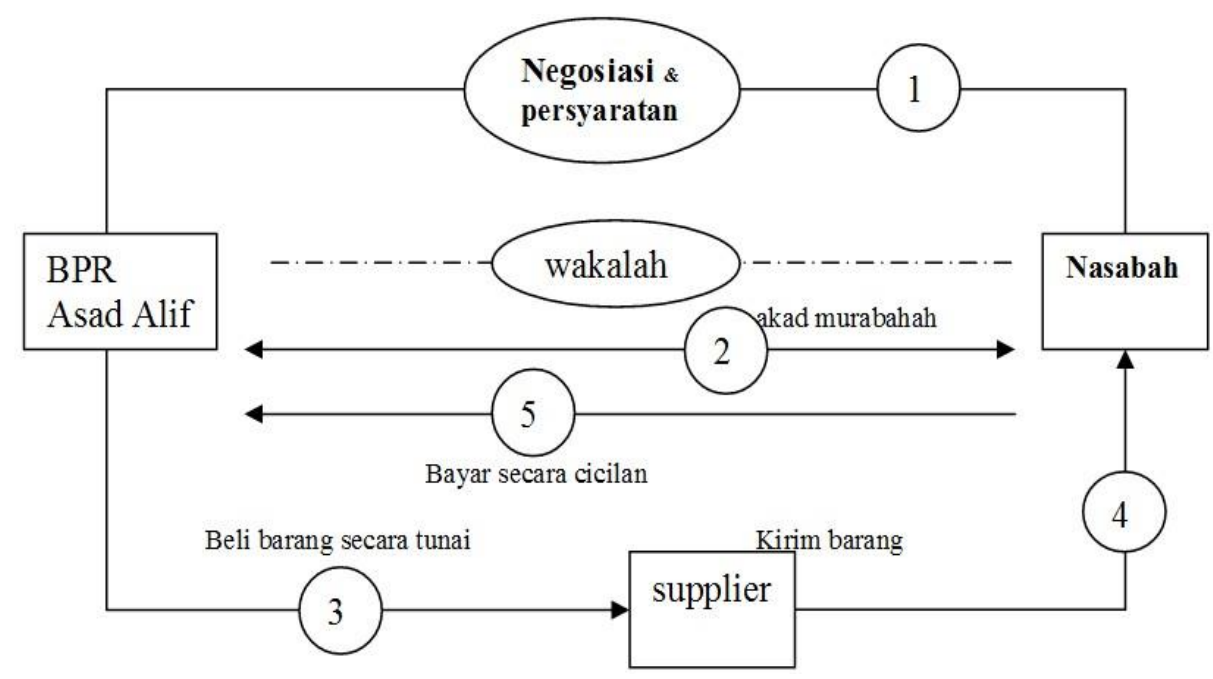

${ }^{24}$ Rahmah Adisty," Penerapan Akad Murabahah Dan Akibat Hukum Dari Penyalahgunaannya Oleh Bank Syariah X Terhadap Nasabah Ditinjau Dari Hukum Islam (Analisis Putusan No. 48 PK/AG/2009)", Jurnal penerapan Akad Fakultas Hukum Universitas Indonesia, 2013, 5.

${ }^{25}$ Burhanuddin S, Aspek Hukum Lembaga Keuangan Syariah (Yogyakarta: Graha Ilmu, 2010), 198.

26 Ulin Nuha, "Analisis Hukum Islam Terhadap Implementasi Pembiayaan Murabahah" dalam http://library.walisongo.ac.id/digilib/files/disk1/84/jtptiain-gdl-mohulinnuh-4157-1-2102172_p.pdf, diakses pada 5 Januari 2017. 
Dari keterangan skema diatas dapat dilihat bahwa bank disini berposisi sebagai pemberi pinjaman bukan sebagai penjual karena pada waktu akad murabahah dilaksanakan barang belum sepenuhnya menjadi milik bank. Apabila kita lihat dalam syarat-syarat murabahah itu sendiri bahwa barang yang ditransaksikan harus sepenuhnya dalam kepemilikan, tidak boleh menjual sesuatu yang dimiliki atau dikuasai seperti yang terjadi pada transaksi short sale dalam pasar modal. ${ }^{27}$

Sedangkan konsep wakalah yang diterapkan dalam sistem murabahah di Bank Muamalat dan Panin Syari'ah bertujuan untuk membantu atau memudahkan nasabah agar dapat membantu hak kepemilikan atas suatu barang yang dikehendaki nasabah. Dengan mendapatkan tambahan modal yang dialokasikan dari bank kepada nasabah lewat transfer atau secara langsung kepada nasabah, nasabah dapat memenuhi kebutuhan akan pembelian suatu barang dengan segera. Solusi pembiayaan bagi nasabah ini ditawarkan dengan model berdikari yang dilakukan oleh nasabah. Artinya, bahwa nasabah nantinya membeli barang yang dikehendaki, bukan dari pihak bank.

Dari konsep wakalah yang diterapkan diatas, penulis dapat menarik kesimpulan bahwa akad yang dilaksanakan Bank Muamalat dan Panin Syari'ah tidak dapat dilaksanakan. Hal ini dapat kita lihat pada rukun dan syarat-syarat wakalah itu sendiri: Muwakil (orang yang berwakil disyaratkan sah melakukan apa yang diwakilkan, sebab milik atau dibawah kekuasaannya) yang syarat-syaratnya harus seorang pemilik sah yang dapat bertindak terhadap sesuai yang ia wakilkan. Muwakil Fiih (sesuatu yang diwakilkan), disyaratkan dimiliki oleh orang yang berwakil ketika ia berwakil dan diketahui dengan jelas. Murabahah, sebagaimana yang digunakan dalam perbankan syari'ah, prinsipnya didasarkan pada dua elemen pokok; harga beli serta biaya yang terkait dan kesepakatan atas mark-up (keuntungan). ${ }^{28}$

\section{KONSEP PENYELESAIAN PEMBIAYAAN MACET DENGAN MENGGUNAKAN PENGALIHAN AKAD}

\footnotetext{
${ }^{27}$ Syafii Antonio, Islamic Banking(Bank Syariah: Dari Teori ke Praktik)(Jakarta: Gema Insani, 2001), 30.

${ }^{28}$ Muhammad, Tehnik Perhitungan Bagi Hasil Dan Profit Margin Pada Bank Syariah (Yogyakarta: UII Press, 2004), 93.
} 
Fungsi bank sebagai lembaga intermediasi keuangan (financial intermediary institution) tersebut sangat menentukan bagi sukses tidaknya pembangunan ekonomi masyarakat. Keberadaan bank dalam hal ini sangat tergantung oleh adanya kepercayaan masyarakat. Prinsip kepercayaan menjadi ruh dari kegiatan perbankan. ${ }^{29}$ Pembiayaan pada Bank Syariah perlu mendapatkan perhatian khusus, baik bagi masyarakat pada umumnya maupun praktisi Bank Syariah pada khususnya, karena kegiatan penyaluran pembiayaan ini merupakan pendapatan utama usaha bank, khususnya pada Bank Syariah. Oleh karena itu, penanganan mengenai pembiayaan ini harus dilakukan dengan sangat hati-hati dan harus dilindungi oleh profesionalisme dan moralitas baik dari pihak bank syariah maupun nasabah bank syariah. Jika tidak ditunjang pada profesionalisme dan moralitas akan menimbulkan beberapa permasalahan pembiayaan salah satunya yang akan mempengaruhi likuiditas, keamanan dan penerimaan bank menjadi rendah sehingga dapat mendatangkan kerugian pada bank dan kemungkinan yang akan terjadi akan mempengaruhi stabilitas perekonomian nasional.

Apabila terjadi pembiayaan bermasalah pada bank syariah, maka diperlukan suatu sistem penyelesaian mengenai pembiayaan bermasalah pada bank syariah secara efisien dan tidak bertentangan dengan peraturan perundang-undangan yang berlaku agar maslaah pembiayaan bermasalah tersebut tidak berdampak pada stabilitas perekonomian nasional.

\section{PENYELESAIAN PEMBIAYAAN MACET}

Aset atau barang pembiayaan murabahah setelah terjadinya akad, sudah beralih kepemilikannya kepada nasabah, tetapi menurut pandangan Islam kepemilikan bukan berarti memberikan hak mutlak cesara bebas bagi pemiliknya, melainkan harus sesuai dengan aturan syariah karena barang atau aset tersebut masih dalam masa cicilan serta untuk mencegah pengalihan barang kepihak ketiga yang dikhawatirkan dapat menyebabkan kredit macet maka jika nasabah ingin menjual kembali aset tersebut kepihak ketiga maka nasabah tetap diwajibkan melapor kepada pihak bank tersebut,

\footnotetext{
${ }^{29}$ Khotibul Umam, "Legislasi Fikih Ekonomi Perbankan: Sinkronisasi Peran Dewan Syariah Nasional Dan Komite Perbankan Syariah", Jurnal Mimbar Hukum Fakultas Hukum Universitas Gadjah Mada Yogyakarta Vol. 24, No. 2, Juni 2012, 2.
} 
dan selain itu pihak nasabah harus segera melunasi cicilan atas aset atau barang tersebut. ${ }^{30}$

Pengertian Bank menurut Undang-Undang RI Nomor 10 tahun 1998 tanggal 10 November tentang Perbankan, adalah badan usaha yang menghimpun dana dari masyarakat dalam bentuk simpanan dan menyalurkannya kepada masyarakat dalam bentuk kredit dan atau bentukbentuk lainnya dalam rangka meningkatkan taraf hidup rakyat banyak. ${ }^{31}$

Bank mempunyai kegiatan usaha khusus seperti yang diatur dalam Pasal 6 dan Pasal 17 Undang-Undang Nomor 7 Tahun 1992 tentang Perbankan Undang-Undang Nomor 10 Tahun 1998 tentang Perubahan Atas UndangUndang Nomor 7 Tahun 1992 tentang Perbankan (selanjutnya disebut Undang- Undang Perbankan), Yaitu :

a) Menghimpun dana dari masyarakat dalam bentuk simpanan berupa Giro, Deposito berjangka, Deposito, Tabungan, dan/atau bentuk lainnya yang dipersamakan dengan itu.

b) Memberikan kredit.

c) Melakukan kegiatan valuta asing dengan ketentuan yang ditetapkan oleh Bank Indonesia.

Analisis dilakukan perbankan untuk mengetahui dan menentukan apakah seseorang itu layak atau tidak untuk memperoleh kredit. Pada umumnya pihak perbankan menggunakan instrumen analisis yang dikenal dengan the five of credit atau the $5 \mathrm{C}$, yaitu character (kepribadian) yaitu penilaian atas karakter atau watak dari calon debitornya, capacity (kemampuan) yaitu prediksi tentang kemampuan bisnis dan kinerja bisnis debitor untuk melunasi hutangnya, capital (modal) yaitu penilaian kemampuan keuangan debitor yang mempunyai korelasi langsung dengan tingkat kemampuan bayar kreditor, condition of economy (kondisi ekonomi) yaitu analisis terhadap kondisi perekonomian debitor secara mikro maupun makro dan collateral (agunan) yaitu harta kekayaan debitor sebagai jaminan bagi pelunasan hutangnya jika kredit dalam keadaan macet. ${ }^{32}$

\footnotetext{
${ }^{30}$ Luthfiyah Trini Hastuti dan Samirah, "Problematika Hukum Penjualan Kembali Aset Yang Belum Lunas Pembayarannya Dalam Pembiayaan Murabahah", Jurnal ekonomi, 2014, 5.

${ }^{31}$ Kasmir, Bank dan Lembaga Keuangan Lainnya (Jakarta: Rajawali Pers, 2011), 25.

${ }^{32}$ Munir Fuady, Hukum Perkreditan Kontemporer (Bandung: PT. Citra Aditya Bakti, 2002), 21.
} 


\section{KESIMPULAN}

Pembiayaan murabahah merupakan pembiayaan berakad jual beli dimana pada dasarnya merupakan kesepakatan antara Bank syari'ah sebagai pemberi modal dan nasabah (debitur) sebagai peminjam. Kedua belah pihak harus menyepakati harga jual dan jangka waktu pembayaran. Harga jual dicantumkan dalam akad jual beli dan jika telah disepakati tidak dapat berubah selama berlakunya akad.Murabahah, sebagaimana yang digunakan dalam perbankan syari'ah, prinsipnya didasarkan pada dua elemen pokok; harga beli serta biaya yang terkait dan kesepakatan atas mark-up (keuntungan).

Karena lebih mudah dan cepat prosesnya dan resikonya lebih kecil maka bankbank syariah pada umumnya mengalihkan akad wakalah pada akad murabahah. Sehingga peminat dari akad murabahah ini lebih banyak digunakan dalam akad penyaluran dana kepada nasabah.

Penelitian ini memberikan kontribusi saran diantaranya: Bagi Bank disarankan untuk lebih aktif dalam Pembiayaan agar para nasabah dapat mengembangkan usahanya. Bagi paraa nasabah apabila mengalami pembiayaan maka dianjurkan untuk beralih kepada akad murabahah yang mudah prosesnya dan kecil resikonya

\section{DAFTAR PUSTAKA}

Ahmad, Idris. Fiqh Menurut Madzhab Syafi'i, jilid II cet. Ke-1. Jakarta: Widjaya, 1969.

Antonio, M. Syafi’i. Bank Syariah Dari Teori Ke Praktek. Jakarta: Gema Insani, 2011. Arifin, Zaenul. Memahami Bank Syari'ah Lingkup Peluang, Tantangan dan Prospek. Jakarta: Alvabert, 2001.

Burhanuddin S. Hukum Kontrak Syariah. Yogyakarta: BPPE Jogjakarta, 2009.

Burhanuddin S. Aspek Hukum Lembaga Keuangan Syariah. Yogyakarta: Graha Ilmu, 2010.

Dewi, Gemala. Aspek-aspek Hukum dalam Perbankan dan Perasuransian Syariah, cet. 3. Jakarta: Kencana Prenada Media Group, 2006.

Fuady, Munir. Hukum Perkreditan Kontemporer. Bandung: PT. Citra Aditya Bakti, 2002. 
karim, Adiwarman A. Bank Islam: Analisis Fiqh dan Keuangan, cet. Ke-2. Jakarta : PT. Raja Grafindo Persada, 2004.

Karim, M.A, Helmi. Fiqh Muamalah cet. I. Jakarta :PT. Raja Grafindo Persada, 1993.

Kasmir. Bank dan Lembaga Keuangan Lainnya. Jakarta: Rajawali Pers, 2011.

Muhammad. Tehnik Perhitungan Bagi Hasil Dan Profit Margin Pada Bank Syariah. Yogyakarta: UII Press, 2004. 